IRSH 59 (20I4), pp. 473-504 doi:10.10I7/S00208590I4000455

(C) 2014 Internationaal Instituut voor Sociale Geschiedenis

\title{
Migration, Minorities, and Radical Networks: Labour Movements and Opposition Groups in Saudi Arabia, 1950-1975*
}

\author{
Tов Y MATthiesen \\ Pembroke College, University of Cambridge \\ Trumpington Street, Cambridge CB2 IRF, UK
}

E-mail: mtm42@cam.ac.uk

\begin{abstract}
AвSTRAст: This article shows how ideas of Arab nationalism, socialism, and communism spread to the Arab Gulf states. It outlines how migrant workers, teachers, students returning from abroad, and the emergence of a print culture filled with Arab nationalist and leftist ideas in the r940s created the basis for widespread political mobilization in the oil-rich Eastern Province of Saudi Arabia. After major strikes in 1953 and 1956 and a harsh crackdown, leftist activists moved underground and into exile. They continued to be active clandestinely and gathered in various capitals in the region. Members of the Shia Muslim minority in the Eastern Province played a special role in the labour movement and secular opposition groups. The latter promised the Shia inclusion in a larger political project and thus they were seen as an antidote to sectarian discrimination against this minority. The article emphasizes the importance of transnational networks, organizational resources such as libraries and social clubs, and a radicalized public sphere for political mobilization.
\end{abstract}

\section{A SUPPRESSED HISTORY}

This article highlights the importance of migrating workers, teachers and students, radical transnational networks, a print culture filled with progressive ideas, and the presence of socio-economic and identitybased grievances for large-scale political mobilization. It also shows how organizational resources and pre-existing interpersonal networks, including family ties, facilitate sustained labour mobilization and strike

* I would like to thank Louis Allday, Khadija von Zinnenburg Carroll, Kamil al-Khatti, and Adrian Ruprecht for their suggestions and comments on earlier versions of this article. I would also like to thank the anonymous reviewers, who provided very detailed comments and suggestions that have improved this article. I am indebted to a number of colleagues that have helped me along the path of researching the history of leftist movements in the Gulf, above all 'Abd al-Nabi al-'Akri. 
organization. The creation of a modern labour force in the oil camps of the Eastern Province of Saudi Arabia was a precondition for labour activism, and the initially very poor living conditions of the workers in these camps was the main grievance that led to two major strikes in 1953 and 1956. After the strikes were broken, strike leaders went on to found an array of secular opposition parties that remained active underground and in exile.

The history of Saudi leftist activism is generally only mentioned in passing in literature on Saudi Arabia and the Arab left. ${ }^{\text {I Some recent }}$ works have highlighted the appeal of Arab nationalism in the Saudi Eastern Province, and the role of nationalist elites in the emerging bureaucracy. ${ }^{2}$ The best accounts are to be found in works by leftist activists from the wider Gulf. ${ }^{3}$

'Ali al-' Awwami, a Shia communist, was the first Saudi leftist to write a comprehensive autobiography. It had to be published posthumously in $20 \mathrm{I} 2$ because of the sensitivity of the topic and is a key source for this article. ${ }^{4}$ Another communist, Ishaq al-Shaykh Ya'qub, a Sunni from the Eastern Province, has published his memoirs.' One former Saudi Baathist, himself a Shia from the Eastern Province, has written articles on the nationalist opposition. ${ }^{6}$ One reason for this relative scarcity of material is

I. The following works mention the leftists: Mordechai Abir, Saudi Arabia: Government, Society and the Gulf Crisis (London, 1993); Fred Halliday, Arabia without Sultans, 2nd edn (London, 2002), pp. 65-69; Helen Lackner, A House Built on Sand: A Political Economy of Saudi Arabia (London, 1978); Ghassane Salameh and Vivian Steir, "Political Power and the Saudi State", MERIP Reports, 9I (1980), pp. 5-22; Ayman Yassini, Religion and State in the Kingdom of Saudi Arabia (Boulder, CO, 1985 ).

2. Toby Craig Jones, Desert Kingdom: How Oil and Water Forged Modern Saudi Arabia (Cambridge, MA, 2010); Robert Vitalis, America's Kingdom: Mythmaking on the Saudi Oil Frontier, 2nd edn (London, 2009).

3. See 'Abd al-Nabi al-'Akri, al-tanzimat al-yasariyya fi al-jazira wa-l-khalij al-'arabi [The Leftist Organizations in the Peninsula and the Arabian Gulf] (Beirut, 2003); Falah 'Abdallah al-Mudayris, al-bathiyyun fi al-khalij wa-l-jazira al-arabiyya [The Baathists in the Gulf and the Arabian Peninsula] (Kuwait, 2002).

4. Sayyid 'Ali al-Sayyid Baqir al-'Awwami, al-haraka al-wataniyya fi al-su'udiyya 1953-1973 [The National Movement in Saudi 1953-1973], 2 vols (Beirut, 2012).

5. See his memoirs: Ishaq al-Shaykh Ya'qub, wujuh fi masabib al-dhakira [Faces of the Lamps of Memory], 4 vols, I (Kuwait, 200I), II (Kuwait, 2005), III (Kuwait, 2007), IV (Beirut, 20I I). For another part of his memoirs and his time in the German Democratic Republic, see idem, inni ashummu ra'ihat maryam [I smell Mariam], II (Beirut, 20I0) and his account of his time as a political prisoner: idem, al-musa'ala [The Interrogation] (Beirut, 20I I). See also idem, $f$ al-thaqafa wa-l-naqd [On Culture and Criticism] (Kuwait, 200I); Ahmad al-Wasil, "al-shuyu'i al-atiq Ishaq al-Shaykh Ya'qub” [The Old Communist Ishaq al-Shaykh Ya'qub], Jadaliyya, 3 May $20 \mathrm{I} 2$.

6. Yusuf Makki, "hizb al-bath al-'arabi al-ishtiraki fi al-'arabiyya al-su'udiyya" [The Arab Socialist Baath Party in Saudi Arabia], in Muhammad Jamal Barut (ed.), al-ahzab wa-l-harakat wa-l-tanzimat al-qawmiyya fi al-watan al-arabi [The Nationalist Parties, Movements and 
that the Saudi dissidents never wrote official histories, nor did they archive their publications and pamphlets in a systematic way. An amnesty in 1975 was granted on the understanding that no-one should talk about the history of subversion and underground movements. Membership in these organizations was punishable by harsh prison sentences, and sometimes even the death penalty, and widespread arrests meant that personal archives were burnt or destroyed in order to hide evidence. ${ }^{7}$

\section{RADICAL NETWORKS AND THE MIGRATION OF IDEAS IN THE MIDDLE EAST}

Radical ideas spread beyond the centres of Empire in the late nineteenth and early twentieth centuries to the eastern Mediterranean and port cities along the passage to India. ${ }^{8}$ The British colonies and dependencies in Mesopotamia and the Gulf were transformed as a result of their integration into the spheres of commerce, migration, and intellectual exchange of Empire. In Iraq, communist movements had developed already in the I920s and particularly the activism in the southern city of Basra had an impact on the Arab Gulf states such as Kuwait. ${ }^{9}$

Given the relative proximity of the Eastern Province to Iraq, Iraq was the dominant influence on political activists in the east and developments in Iraq were strongly reflected on the Arab side of the Gulf. After the Baath Party took power in Iraq and came into conflict with the Iraqi communists, this split the leftists and nationalists in the Gulf along those lines as well. ${ }^{1 \circ}$ The Shia of Qatif and al-Ahsa in particular had long-standing

Organizations in the Arab Homeland] (Beirut, 20I2), pp. 29I-30I; idem, "harakat al-qawmiyyin al-'arab fi al-khalij wa-l-jazira al-'arabiyya" [The Movement of Arab Nationalists in the Gulf and the Arabian Peninsula], in Barut, al-abzab, pp. 467-486; idem, "al-haraka al-nasiriyya fi al-arabiyya al-su udiyya" [The Nasserist Movement in Saudi Arabia], in Barut, al-abzab, pp. $672-680$.

7. Many leftists are still afraid to talk about their political activities, partly as a result of years of imprisonment and torture. Nevertheless, I was able to interview some veterans of different Saudi and Gulf leftist movements, and managed to find hitherto unexamined propaganda publications. I mainly found these journals and books in private collections across the Middle East, including in Saudi Arabia, Bahrain, Kuwait, and Lebanon, as well as in libraries in Europe and the United States. These sources are complemented by American diplomatic records and internal documents of the Arabian American Oil Company (ARAMCO). While ARAMCO company archives are not open to researchers, parts of the archives were copied and are available in the William E. Mulligan Papers, Georgetown University, Washington, DC [hereafter, Mulligan Papers].

8. Ilham Khuri-Makdisi, The Eastern Mediterranean and the Making of Global Radicalism, I860-I9I4 (Berkeley, CA, 20I0).

9. Interview with Kadhim Habib, an Iraqi communist, Berlin, 2014.

Io. Interview with Muhammad al-'Ali, a former Saudi leftist activist, LBC Television, 2008, available at http://www.youtube.com/watch?v=SzJNRW 933 Pwk\&list $=\mathrm{PL}_{3} \mathrm{BF}_{2} \mathrm{CF} 6 \mathrm{~F} 800{ }_{4} \mathrm{C}_{7} \mathrm{~B}$. 


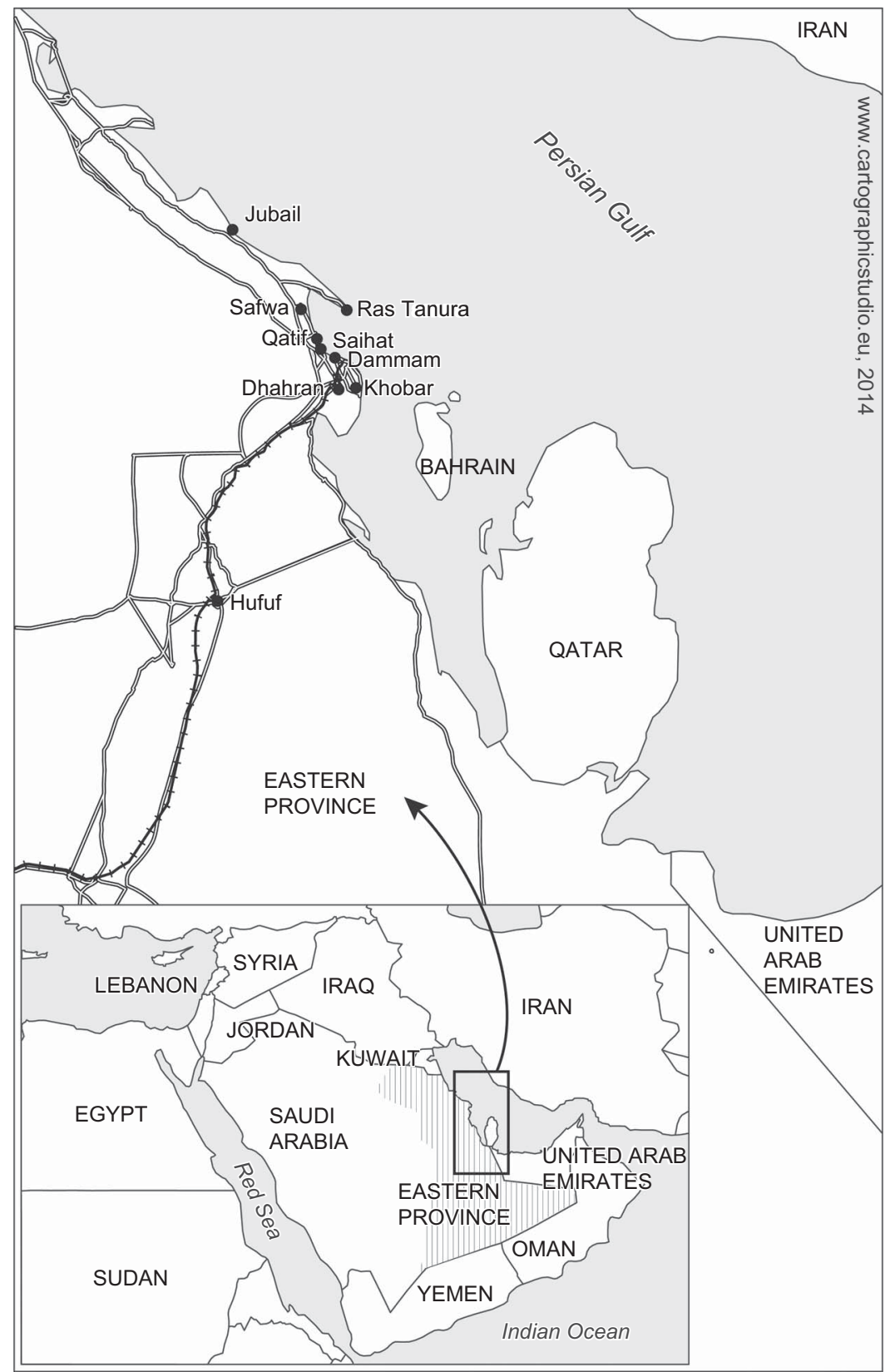

Figure I. Map of the Eastern Province of Saudi Arabia in the late 1950s. 
religious and business links with Iraq, and travelled regularly to Iraq. These connections also facilitated the flow of political ideas from Iraq to the Eastern Province.

The British protectorate island of Bahrain, especially its capital Manama, also has long experienced anti-colonial activism. Clandestine networks, civil society organizations, and a radical press emerged there in the first half of the twentieth century. ${ }^{\mathrm{II}}$ Given that Bahrain was just a short boat ride from the port cities of eastern Arabia, radical ideas and publications often reached the Saudi mainland via Bahrain. Family ties between the Eastern Province and Bahrain were also key.

While the Eastern Province was the main base of leftist ${ }^{12}$ and nationalist movements in Saudi Arabia, they also had supporters in Riyadh, the Hijaz, and other parts of the country, but there is even less information on activism in these regions than on the Eastern Province. ${ }^{\mathrm{I}}$

Particularly since the I940s, members of the local upper class and employees in the nascent oil industry received a modern education either in Bahrain or in the intellectual centres of the Arab world such as Baghdad, Beirut, or Cairo. There they became familiar with the ideas of Arab nationalism and communism.

Since the mid-I930s and especially since the discovery of oil in 1938 the local oil company, which was renamed the Arabian American Oil Company (ARAMCO) in 1944, recruited thousands of foreigners and people from the Eastern Province. While Saudi employees were initially mainly unskilled workers, Palestinians, Syrians, Egyptians, Lebanese, Italians, Sudanese, Indians and others came to the Eastern Province to carry out semi-skilled work. These expatriate workers from countries with a longer history of radical activism intermingled with the Saudi workforce and disseminated radical ideas. They were communists, Baathists, pan-Arab nationalists, Syrian nationalists, and Nasserists. Far from spreading the orthodox thoughts of one particular line of left-wing

See also Saeed Khalil Hashim, The Influence of Iraq on the Nationalist Movements of Kuwait and Babrain 1920-I96I (Ph.D., University of Exeter, 1984).

I I. Nelida Fuccaro, Histories of City and State in the Persian Gulf: Manama since I800 (Cambridge, 2009), pp. I I-I90.

I 2. Many of the people that were later locally referred to as "leftists" probably subscribed to a mildly socialist and anti-colonial nationalism and probably less to orthodox Marxism. Constitutionalism, "republicanism", and the notion that contracts with Western oil companies should be renegotiated so that more wealth stayed within developing countries were widespread sentiments in the region.

I3. One exception is Muhammad Sa id Tayyib, a prominent Nasserist lawyer and opposition activist from Jeddah, who published a collection of interviews and articles about his life that include details of the Nasserist movement in the Hijaz: Ahmad 'Adnan, al-sajin 32: ablam Muhammad Sa'id Tayyib wa-haza'imbu [Prisoner 32: The Dreams of Muhammad Sa'id Tayyib and his Defeats] (Beirut, 20I I). 


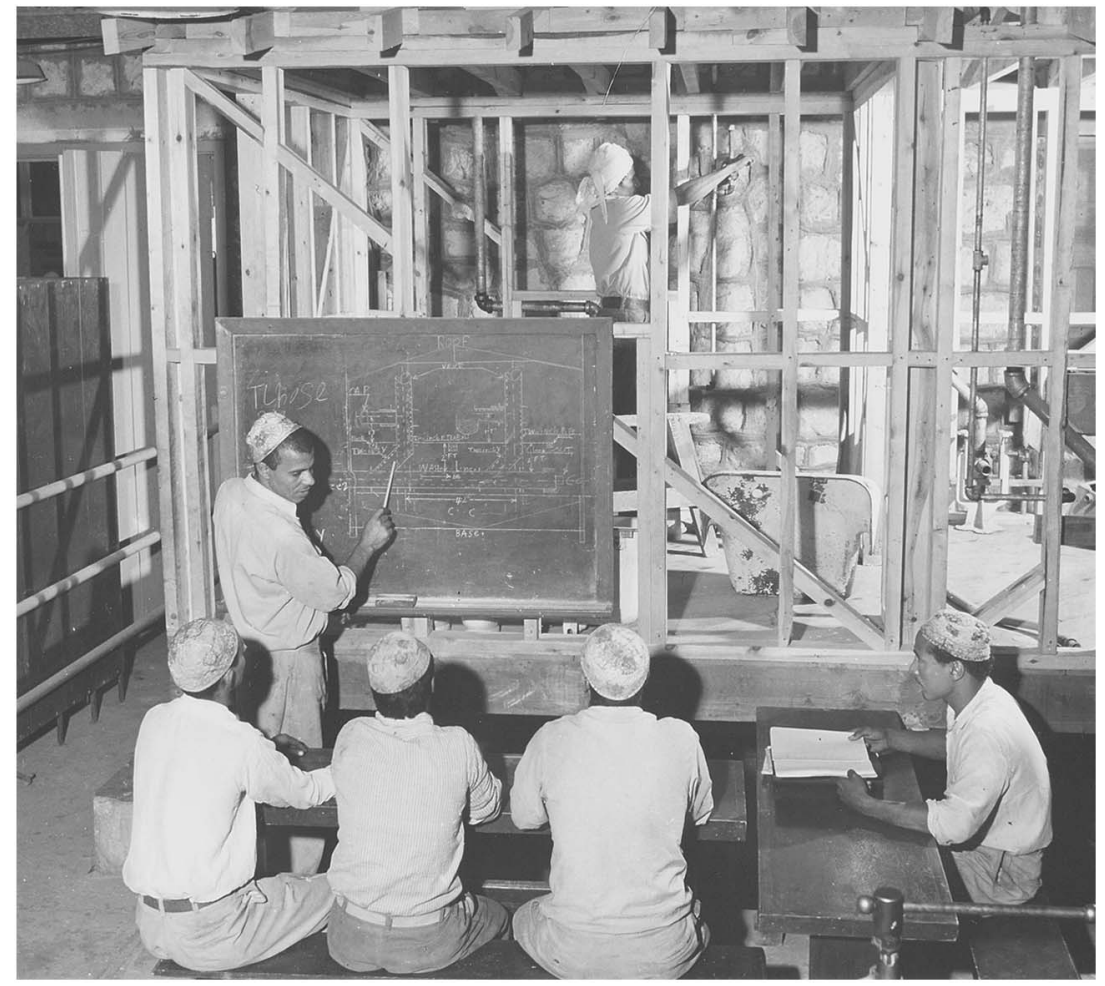

Figure 2. Aramco School in Dhahran, Saudi Arabia.

Unknown photographer/Saudi Aramco World/SAWDIA. Used with permission.

ideology, a general sense of radical politics spread in the labour camps of ARAMCO, the emerging oil towns of Damman and Jubail, and the community centres of the Shia port city of Qatif. The Gulf region as a whole became a transnational field, in which ideas, students, and revolutionaries travelled across national borders and increased political mobilizations in other countries. ${ }^{\mathrm{I}}$

Particularly important were teachers in ARAMCO schools, ${ }^{15}$ most of whom were Lebanese or Palestinians. Some of them had been members

I4. For the idea that migration increased political mobilization in the Gulf states in the 1950s and i96os, see John Chalcraft, Monarchy, Migration and Hegemony in the Arabian Peninsula (London, 2010).

I5. The oil company established schools for its employees and sent some Saudis abroad for training. It produced a wide range of corporate propaganda, showing off the infrastructure and "development" projects it undertook across the Eastern Province. These and similar pictures, highlighting the "modernity" that the company was bringing to Arabia, were distributed in 


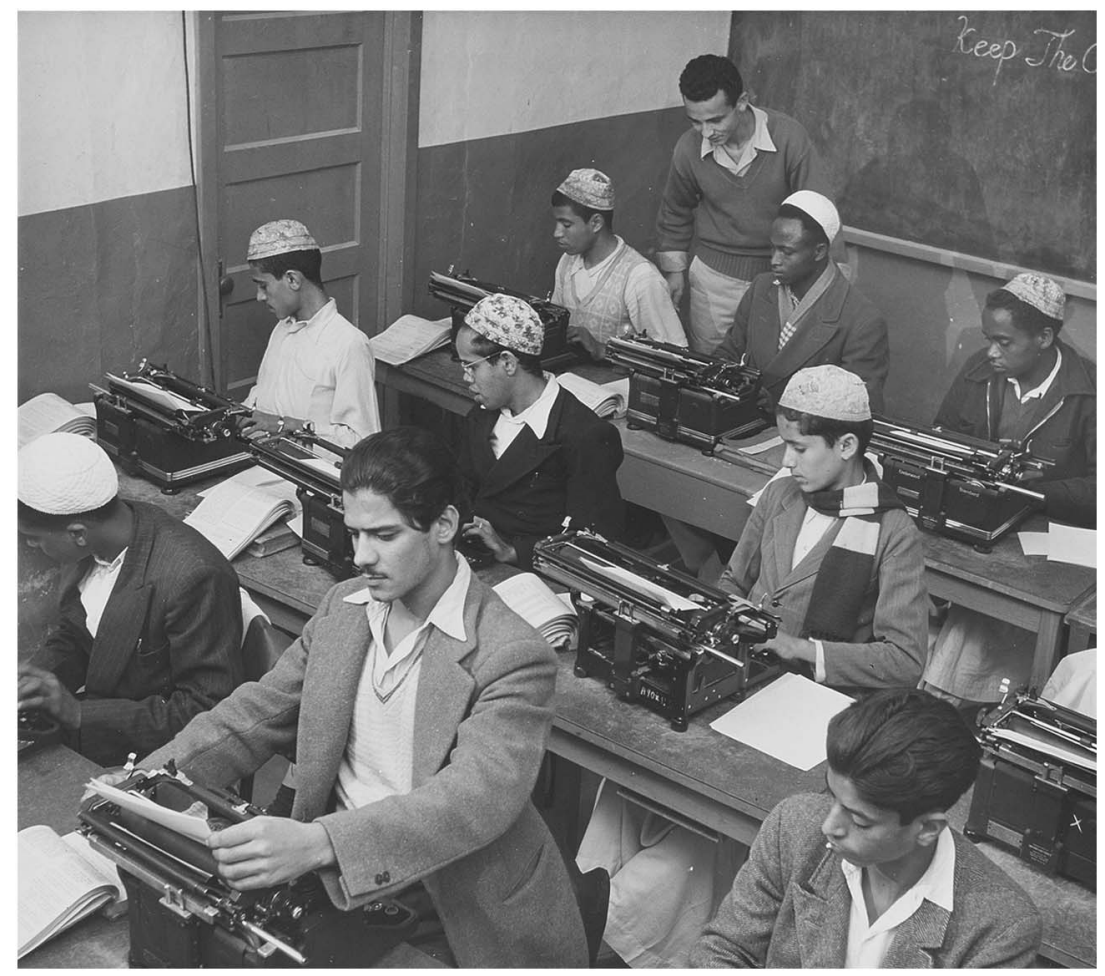

Figure 3. Aramco School in Dhahran, Saudi Arabia.

Unknown photographer/Saudi Aramco World/SAWDIA. Used with permission.

in left-wing political parties in their countries of origin and discussed radical ideas with their students and started to distribute forbidden political literature. They secretly circulated the magazines of the Lebanese Communist Party, al-Sarkha and al-Nida', amongst students and ARAMCO workers. ${ }^{16}$ A local trader in Qatif, who sensed that he could do business with students from ARAMCO schools that were keen to get their hands on the likes of Karl Marx and Friedrich Engels, opened a bookshop in Qatif and started to import the classics of the global left. It was seemingly the only bookshop in the Eastern Province that sold forbidden literature, including much of the communist and Arab left canon, but also Russian novels and plays. Hence, the young, aspiring

company publications, including its journal Aramco World. For a more recent take on this genre see Ismail I. Nawwab, Peter C. Speers, and Paul F. Hoye (eds), Saudi Aramco and its World: Arabia and the Middle East (Dhahran, 1995).

I6. Al-'Awwami, al-haraka al-wataniyya, I, pp. 65-77. 
leftists from other cities in the Eastern Province came to Qatif to buy these books. ${ }^{17}$

\section{"SHI'I-SHUYU'I": RADICAL IDEOLOGIES AND THE SHIA OF QATIF}

The discourses and networks of Arab nationalism, socialism, and anticolonialism became also related to the struggle of the sizeable Shia community in the Eastern Province against religious and political discrimination. This was not a solitary phenomenon. Arab Shia communities in Iraq, Lebanon, and Bahrain also became backbones of communist parties in these countries. Sons of wealthy notables and prominent clerics turned their backs on religion and saw in communism a new ideology of salvation. This phenomenon was called "Shii-shuyu'i", Shia-communist, playing on the common linguistic roots of the two terms in Arabic. ${ }^{18}$ In fact, many members and cadres of the clandestine Saudi leftist groups were natives from the Eastern Province, and many of them were Shia.

As mentioned, not only workers or peasants were attracted by these groups, but also members of the local upper class of notable families. The notable families had for centuries played an important social, political, and religious role in the Shia communities of Qatif and al-Ahsa, the old urban centres in the area before the establishment of the new oil towns. ${ }^{19}$ They had been intermediaries between the powers of the day and the local population. After the Saudi conquest in I9I3, however, these families suffered, as did all Shia in the Eastern Province, from religious and

17. At the same time as selling the Communist Manifesto to the young leftists (al-'Awwami refers to his group as al-shabab, the youth), the owner, 'Abd al-Hamid al-Zayir, also sold Shia books to the clerics and religiously minded people of Qatif. Perhaps ironically, it was more the selling of Shia books than of leftist literature that attracted the attention of the censors in the Eastern Province; Al-'Awwami, al-haraka al-wataniyya, II, pp. 49-56. Shia religious books are up to today frequently banned in Saudi Arabia.

I8. For a discussion of this term with reference to Lebanon and Iraq see: Silvia Naef, "Shī'īshuyūī or: How to become a Communist in a Holy City", in Rainer Brunner and Werner Ende (eds), The Twelver Shia in Modern Times: Religious Culture E Political History (Leiden, 200I), pp. $255-267$.

19. Saudi Shia number between 10 and is per cent of around 25 million citizens in contemporary Saudi Arabia. For more, see Hamza al-Hasan, al-shi a fi al-mamlaka al-arabiyya al-suindiyya [The Shia in the Kingdom of Saudi Arabia], 2 vols (Beirut, I993); Ibrahim al-Hatlani, al-shi'a al-su'udiyyun: qira'a tarikhiyya wa-siyasiyya li-namadhij matlabiyya [The Saudi Shia: A Historical and Political Reading of Sample Claims] (Beirut, 2009); Fouad Ibrahim, The Shi is of Saudi Arabia (London, 2006); Badr al-Ibrahim and Muhammad al-Sadiq, al-hirak al-shii fi al-suindiyya: tasyis al-madhbab wa-madhbabat al-siyasa [The Shia Movement in Saudi: The Politicization of Confession and the Confessionalization of Politics] (Beirut, 2013); Laurence Louër, Transnational Shiite Politics: Religious and Political Networks in the Gulf (London, 2008); Toby Matthiesen, The Other Saudis: Shiism, Dissent and Sectarianism (Cambridge, 2015). 
institutional discrimination, conversion attempts, special levies, and a general sense of exclusion from the new state that would become Saudi Arabia.

When the labour movement at ARAMCO gained pace, many young Shia notables were thrilled by the non-sectarian and all-encompassing discourse of Arab nationalism and socialism. They saw themselves as enlightened intellectuals who wanted to lead the oil workers and peasants, and they mainly recruited their fellow activists from the ranks of their close friends, colleagues, or family members.

Hasan al-Jishi, who eventually became the "mayor" of Qatif, is exemplary in this regard. Hasan was born in Qatif in I9I 8 into one of the wealthiest pearl trading and clerical families in the area. Symbolizing the interconnectedness of the Saudi mainland and the island of Bahrain, branches of the al-Jishi family also lived in Bahrain. There they also became one of the most prominent Shia families and co-founded the local branch of the Baath Party. ${ }^{20}$ Therefore, it seemed only natural for Hasan to move to Bahrain in 1930 after the death of his father to live with his relatives. He had studied in the local informal religious school in Qatif but in Bahrain went to study at a Geographical School. He worked part-time in the pearl business and at the age of sixteen joined BAPCO (Bahrain Petroleum Company), where he learned English. This enabled him to get a job in the ARAMCO Geographical Department in 1938 and so he moved back to Qatif where he would play an important role in the dissident activities to emerge from the late I940s onwards. ${ }^{2 \mathrm{I}}$

\section{INSTITUTIONALISING DISSENT: LIBRARIES, NEWSPAPERS, AND THE EMERGENCE OF A PUBLIC SPHERE}

Hasan al-Jishi and a number of other Shia intellectuals such as 'Abdallah al-Jishi (his cousin) or 'Abd al-Ru'uf al-Khunayzi decided in the late I940s that the political and cultural awareness of the local population

20. Jamil bin 'Abdallah al-Jishi, turath al-ajdad: dirasa fi watha'iq 'a'ilat al-jishi fi al-Qatif wa-l-Babrayn (I200-I350 A.H.) [Heritage of the Forefathers: A Study of the Documents of the al-Jishi Family in Qatif and Bahrain (1786-193I)] (Jeddah, 2007); interview with a former leader of the Bahraini Baath Party, Bahrain, 20I I (identity in possession of the author - this also applies to subsequent footnotes where interviewees are cited without names).

21. For his biography, see: al-'Awwami, al-haraka al-wataniyya, I, pp. 165-167; al-Jishi, turath al-ajdad, pp. 349-35r; Anonymous, "min qawafil al-shuhada': al-shahid Hasan Salih al-Jishi" [From the Colons of Martyrs: The Martyr Hasan Salih al-Jishi], Sawt al-Talia, 8 (I974), pp. 52-62. Sawt al-Tali a, launched in 1973, was the periodical of the Saudi Baath Party branch sponsored by Iraq and constitutes an important source for the history of radical opposition groups in Saudi Arabia. 
should be raised. Several of these figures had been educated abroad. 'Abdallah al-Jishi, for example, was born in Najaf, where he also studied. In 1948, he returned to Qatif, where his father took on the position of Shia judge. ${ }^{22}$ "Abdallah helped his father for a while in the Shia court until he started working with the leftist labour official 'Abd al-'Aziz bin Mu'ammar. ${ }^{23}$

These Shia notables laid the nucleus of political activism in Qatif in I 948/9, when they formed jami iyyat al-ilm li-1-nidal (Knowledge Society for the Struggle). This secret organization wanted to raise the local political awareness through education and the building of cadres and was known publicly as lajnat tashjia al-tullab (Committee for the Advancement of Students) founded in 1950 with 'Abdallah al-Jishi as secretary. The committee provided help to students from poorer backgrounds who studied in the first government-run primary school in Qatif, which was founded in $1948 .^{24}$ The Committee also opened a centre in Qatif with a library of "progressive" literature, the first evening school in the area, and a theatre. In these facilities jami iyyat al-ilm li-l-nidal tried to spread its ideas through gatherings, lectures and plays. Although the authorities closed down the centre after just seven months, jamiciyyat al-ilm li-l-nidal continued to operate secretly. It was also behind the Qatif public library, which was founded in 1955 and was closed and reopened repeatedly throughout the 1950 s and 1960 s. $^{25}$

The public figure associated with the library was Hasan al-Jishi, who organized the funding for it, was the head of its governing body, and interacted with the authorities. 'Ali al-'Awwami was the secretary, and his brother Hasan member of the governing board, while 'Abd al-Wahid al-Khunayzi was the treasurer. Several young activists donated books to the library. Also, several Arabic periodicals were on display in the library. Qatif then became firmly integrated into the discourses and political dynamics of the wider Arab world. Although it is difficult to know how many people actually used this library, it was, especially for young, literate and male residents of Qatif, the main place to read, socialize in the evenings, and discuss. When many of its organizers were arrested in the I956 crackdown on the labour movement, the library was closed and its books moved to a small shop in the old town of Qatif. When another

22. The Shia judges of Qatif and al-Ahsa had limited jurisdiction over personal status law and inheritance. See Matthiesen, The Other Saudis, ch. I.

23. For biographical information on 'Abdallah al-Jishi, see al-'Awwami, al-haraka al-wataniyya, I, p. 162, and al-Jishi, turath al-ajdad, pp. 317-331. There were rumours that his arrest in 1955 was because he was suspected of being the representative of the Iraqi Communist Party in Qatif; Al-'Awwami, al-haraka al-wataniyya, I, pp. I04f., I64f.

24. Ibid., I, pp. II7-I I9.

25. Sawt al-Talia, I (1973), pp. 23 f.; 8 (1974), pp. 52-62. 


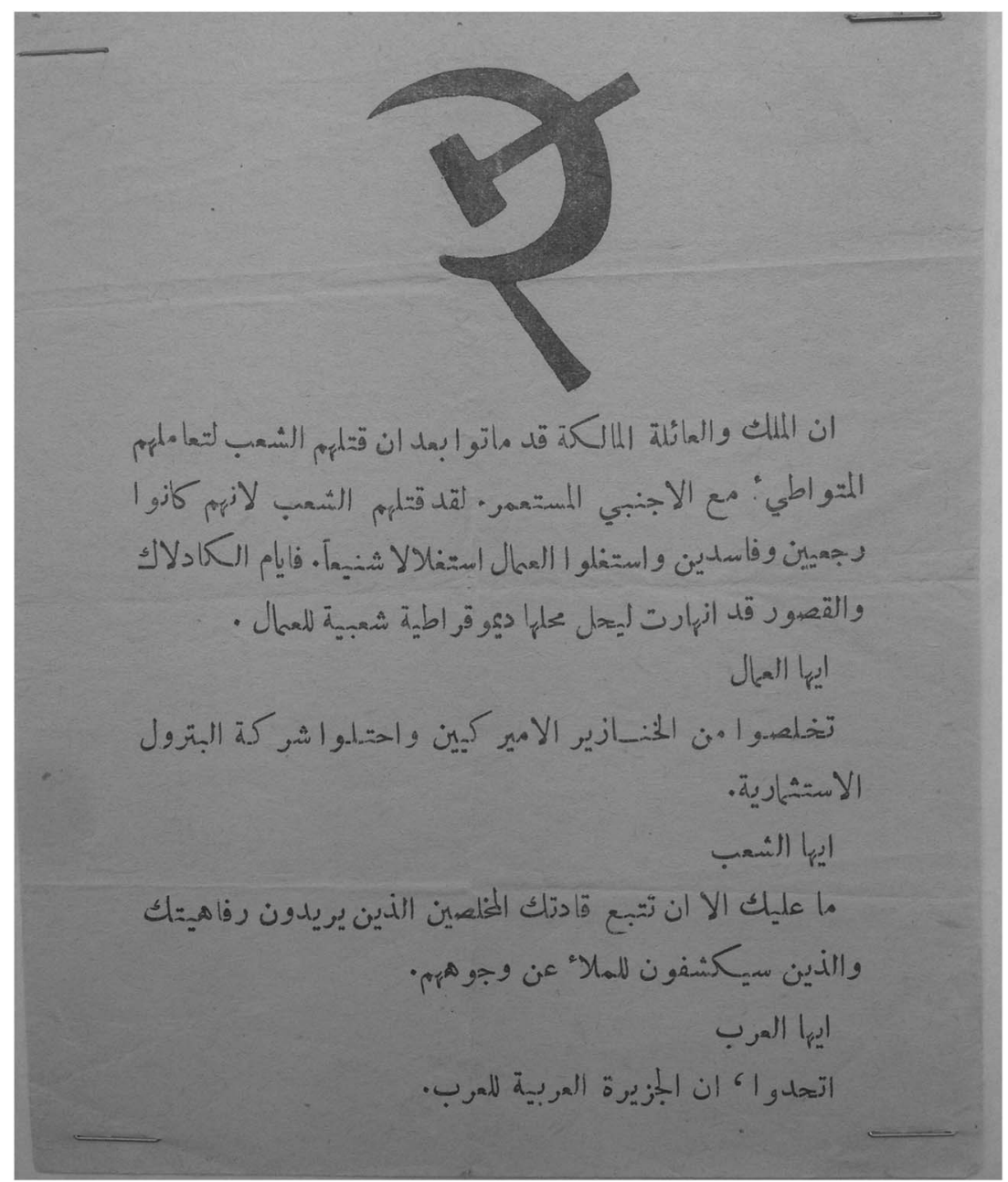

Figure 4. Leaflet distributed in Khobar on 19 and 20 August 1954. National Archives at College Park, Maryland, RB 59, 786A.00/8-3054. ${ }^{26}$

group associated with the library was arrested in 1957, the library reopened, but severe ideological splits started to emerge amongst the activists of Qatif, as a reflection of the divisions in the wider Arab world, between Baathists, Nasserists, Arab nationalists, and communists.

26. "Certainly the King and the royal family have died after the people killed them because of their joint actions with the foreign imperialists. Certainly the people killed them because they were reactionaries and corrupt and exploited the workers terribly. The days of the Cadillac and 
These also had an effect on the library, and the competing ideological groups would even question the right of admission to the library for those adhering to other ideological currents. ${ }^{27}$

This library was known in the wider Gulf region. One veteran Bahraini labour activist, who worked in Dammam in the mid-r96os and liaised with local Saudi activists, remembered how impressed he was by the library in Qatif and stated that it was bigger than libraries in most other areas of the Gulf. ${ }^{28}$ The library, however, was not the only place of politization. "Communist-inspired pamphlets" (see Figure 4), informal study circles, journals, and newspapers intended to achieve the same result. ${ }^{29}$

Overcoming division between Sunni and Shia Muslims was an important part of these political efforts and the Qatifi Shia of jamiciyyat al-ilm li-l-nidal started cooperating with young Sunni men in Jubail in I950 and they legally published a number of issues of the weekly al-Fajr al-Jadid (The New Dawn) in I955. This paper was officially published by the two brothers Yusuf and Ahmad al-Shaykh Ya'qub but served as an outlet for leftist activists and those who had emerged as leaders during the 1953 strike. ${ }^{\circ}$ But the paper was closed down again soon after its editor, Yusuf al-Shaykh Yaqub, had been accused of offending the Interior Minister. The young leftists from Qatif sent a petition to King Sa ud asking for the permission to resume publication, and Hasan al-Jishi went to talk to the governor of the Eastern Province, but to no avail. ${ }^{\text {I }}$ Those behind al-Fajr al-Jadid also established the Dammam public library in I955, for which they secured donations from ARAMCO. ${ }^{32}$

the palaces are finished to give way to popular democracy for the workers. O workers! Get rid of the American pigs and seize the exploiting oil company. O people. You have nothing to do but follow your sincere leaders who seek your welfare and who will reveal their faces to the public. O Arabs. Unite because the Arabian Peninsula is for the Arabs." The leaflet is translated in the US Diplomatic Cable, from American Consul Dhahran, Saudi Arabia, to Department of State, Washington, 30 August I954, RG 59, 786A.00/8-2554, National Archives at College Park, Maryland, as well as in Vitalis, America's Kingdom, pp. i $56 \mathrm{f}$.

27. Al-'Awwami, al-haraka al-wataniyya, I, pp. I20-I 3 I.

28. Interview with a Bahraini leftist, Bahrain, $20 \mathrm{I}$.

29. K.E. Evans (ed.), US Records on Saudi Affairs, 1945-1959, 8 vols (Slough, I997), II: Internal and Foreign Affairs 1950-1954, pp. 621-625; Robert L. Jarman (ed.), Political Diaries of the Arab World: Saudi Arabia 1919-1965, 6 vols (Slough, 1998), VI: Periodic Despatches and Annual Reviews $1941-1965$, p. 213.

30. For example for 'Abd al-'Aziz al-Sunayd, Muhammad Hawshan, 'Abd al-Rahman al-Mansur, and 'Abd al-Rasul ('Abdallah) al-Jishi.

31. Al-'Awwami, al-haraka al-wataniyya, I, pp. I05-107; Evans, US Records, IV: Internal Affairs $1955-1958$, p. 250.

32. H.C. Mueller, The Dammam Public Library, Dammam, I7 July 1955, Box 2, Folder 48, Mulligan Papers. 


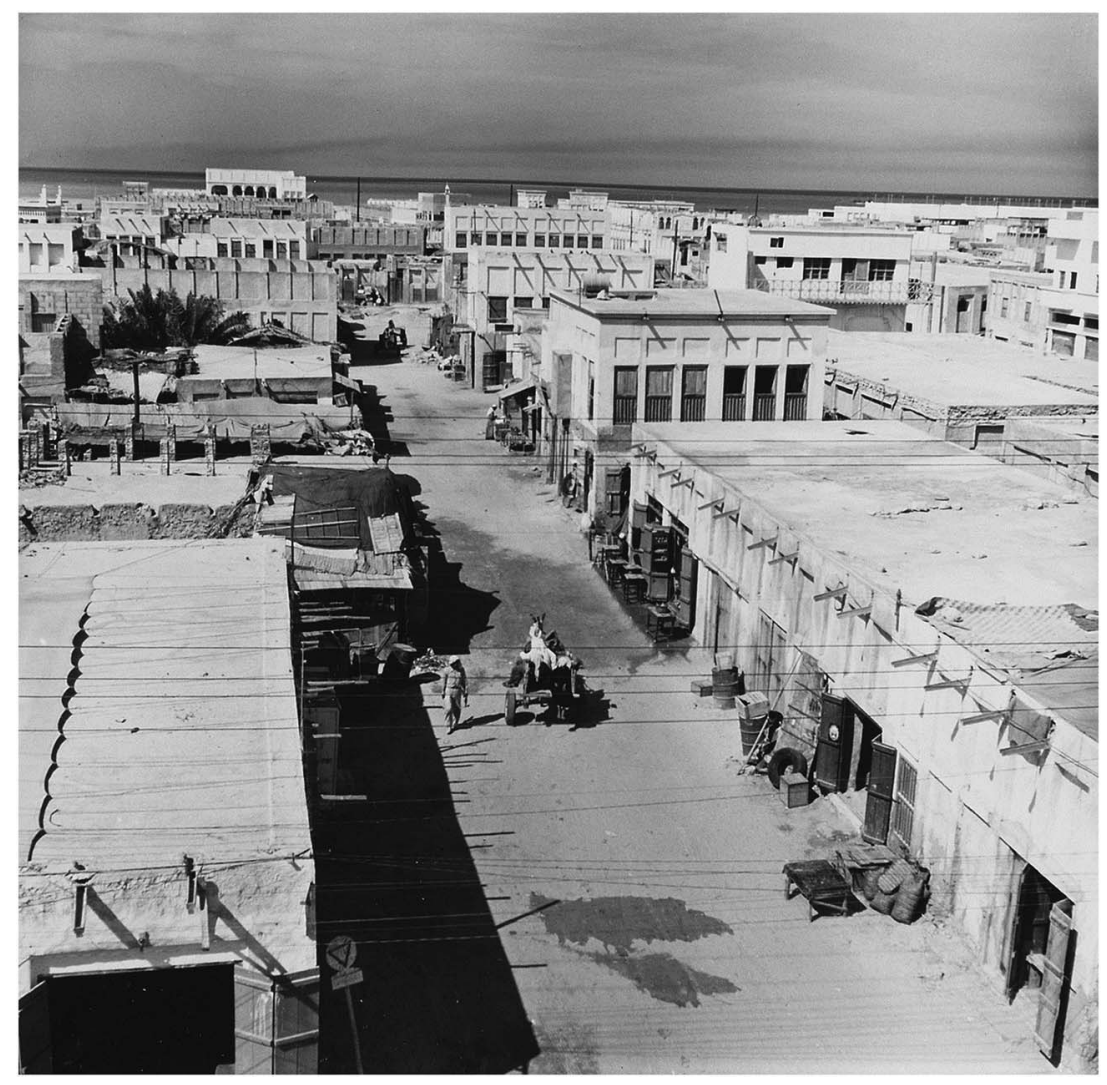

Figure 5. Street scene in Dammam.

Dorothy Miller/Saudi Aramco World/SAWDIA. Used with permission.

In I953, one of those behind jamiinyat al-ilm li-l-nidal wanted to establish a newspaper called al-Jazira (The Island) but was denied permission by the authorities. ${ }^{33}$ This was part of a push for a relatively free, albeit short-lived press in the Eastern Province in the mid-I950s that also included Akbbar al-Dhabran (Dhahran News) and the cultural journal al-Ish'a (The Shining Light), which was published in Khobar from i 955 to $1957 .{ }^{34}$ These newspapers were filled with letters and editorials discussing the Arab Nation and community grievances. "The appropriation of Arab nationalism" in these papers increasingly A Social and Literary Monthly Magazine] (Riyadh, 2010). 
became a "framework for criticizing the Saudi state and critiques of development". 35

This press, particularly the cultural journal al-Isbiac, was influenced by earlier publications in Bahrain such as Sawt al-Babrayn (Voice of Bahrain). ${ }^{36}$ This journal, published from 1950 to 1954, had become a platform for progressive Arab nationalist writers from the Gulf, including many Saudis. 'Abd al-Rasul ('Abdallah) al-Jishi, for example, the leftist activist from Qatif, was a frequent contributor. ${ }^{37}$ It was circulated in the wider Gulf area and featured articles about the Eastern Province, including the labour mobilization at ARAMCO.$^{38}$ Sawt al-Babrayn served as a "launching pad" for the cross-sectarian nationalist political movement in Bahrain, the High Executive Committee (al-Hay'a al-Tanfidhiyya al-'Uliya). This committee became the driving force of popular protests in Bahrain in the 1950s, and it had a strong impact on the Saudi mainland. ${ }^{39}$ Indeed, the activists in Saudi closely followed political developments in Dubai, Kuwait, and Bahrain, where urban riots occurred, anti-colonial movements flourished, and some pushed for the establishment of elected parliaments. ${ }^{40}$ Bahrain also served as a place for the organization of strikes and protests and the strengthening of clandestine networks. Some of the organized workers from ARAMCO would head to Bahrain on the weekends to enjoy the more liberal atmosphere, and plan their next moves. ${ }^{4 \mathrm{I}}$

\section{THE 1953 STRIKE: MIGRANT WORKERS, ORGANIZATIONAL RESOURCES AND ATTEMPTS AT UNIONIZATION}

The limited number of sources available and the widespread use of pseudonyms in publications make it difficult to identify systematically actors present both in the dissident milieus described above and the subsequent

35. Toby Craig Jones, The Dogma of Development: Technopolitics and the Making of Saudi Arabia 1950-I980 (Ph.D., Stanford University, 2006), p. 170.

36. Some leftists in Qatif even tried to establish a monthly magazine called Sawt al-Jazira [Voice of the Peninsula] modelled on Sawt al-Babrayn, but they did not obtain permission; Al-'Awwami, al-haraka al-wataniyya, I, pp. I08-i I I, I67.

37. 'Abd al-Rasul is a distinctively Shia first name that was then banned in Saudi Arabia, and so 'Abd al-Rasul al-Jishi had to be renamed 'Abdallah al-Jishi.

38. Muhammad 'Abd al-Rizaq al-Qasha'mi, al-kuttab al-su'udiyyun fi majallat (Sawt al-Babrayn) 1369-1373 [The Saudi Writers in the Magazine (Voice of Babrain)] (Riyadh, 2010). See the facsimile: Sawt al-Babrayn: majalla adabiyya ijtimaiyya [The Voice of Babrain: A Social and Literary Magazine], 4 vols (Muharraq, 2003).

39. Fuccaro, Histories of City and State in the Persian Gulf, p. I79.

40. Al-'Awwami, al-haraka al-wataniyya, I, p. i 8.

4I. Interview with 'Ali al-Yami, who participated in the labour mobilization at ARAMCO, Washington, 20I3. 
AMRACO labour mobilizations. From the sequence of events, the demands raised, and the political and ideological references used, however, it is more than plausible to infer that the grass-roots activism around Qatif, the revolutionary atmosphere in the region and the radical press conditioned the strikes in the oil sector. These factors, the personal networks, and organizational resources all enabled the labour movement, and ensured that it had support in surrounding communities outside the labour camps and that it was able to sustain itself for a certain period of time.

The first recorded labour mobilizations at ARAMCO occurred on I I June I945, when hundreds of workers rioted at the Ras Tanura refinery over poor food supplies and harassment by company guards. On I 2 July I945 I37 Arab drillers in Dhahran began a strike over unequal pay and benefits in comparison with American and other foreign workers. Over the coming weeks, I,700 Italian workers joined the strike, and on 4 August "the entire labor force of 9000 Arabs employed in Dhahran, Ras Tanura and the outlying worksites" resumed a strike against ARAMCO. ARAMCO was eventually forced to negotiate with a workers' committee chosen by the local governor to end the strike. ${ }^{42}$ Around 800 Italian workers again went on strike for a week in May i947. The strike ended with a mass resignation and the repatriation of 40 per cent of the Italian workers to Eritrea, from which they had come to Saudi Arabia in the first place. $^{43}$

However, the largest strikes occurred in 1953 and 1956 and were jointly organized by Saudis and Arab expatriates. ${ }^{44}$ In 1953, a labour committee made up of seven Saudis who had been sent abroad to study in the US and in Beirut, demanded better conditions for Saudi workers. ${ }^{45}$ It presented petitions to both ARAMCO and the Saudi government and demanded to be recognized as the legitimate representative of the ARAMCO workers, a demand that would have amounted to an effective unionization of the Saudi

42. Vitalis gives the most detailed accounts of the strike movements in the I940s and I950s in the Saudi oil industry. He largely bases his analysis on the Mulligan Papers and American diplomatic records; Vitalis, America's Kingdom, pp. 92-95.

43. Ibid., pp. Iorf.

44. The strikes are discussed and/or documented in: James Buchan, "Secular and Religious Opposition in Saudi Arabia", in Tim Niblock (ed.), State, Society and Economy in Saudi Arabia (London, I982), pp. III-II3; Michael Sheldon Cheney, Big Oilman from Arabia (London, 1958), pp. 260-275; Evans, US Records, IV, pp. 33-367; Jarman, Political Diaries, VI, pp. I92f.; Tawfiq al-Shaykh, al-batrul wa-l-siyasa fi al-mamlaka al-arabiyya al-suindiyya [Oil and Politics in the Kingdom of Saudi Arabia] (London, 1988), pp. 326-350; Penelope Tuson and Anita Burdett (eds), Records of Saudi Arabia: Primary Documents 1902-1960, 10 vols (Slough, 1992), VIII: 1946-1953, pp. 735-753; Alexei Vassiliev, The History of Saudi Arabia (London, 2000), pp. 336-340.

45. They were 'Abd al-Aziz al-Sunayd, Salih Sa'd al-Zayid, Ibrahim al-Faraj, 'Abdallah al-Ghanim, 'Abd al-Rahman al-Bahijan, 'Umar Wazna, 'Abd al-'Aziz al-Sufiyyan; Vitalis, America's Kingdom, pp. I45-I49. 


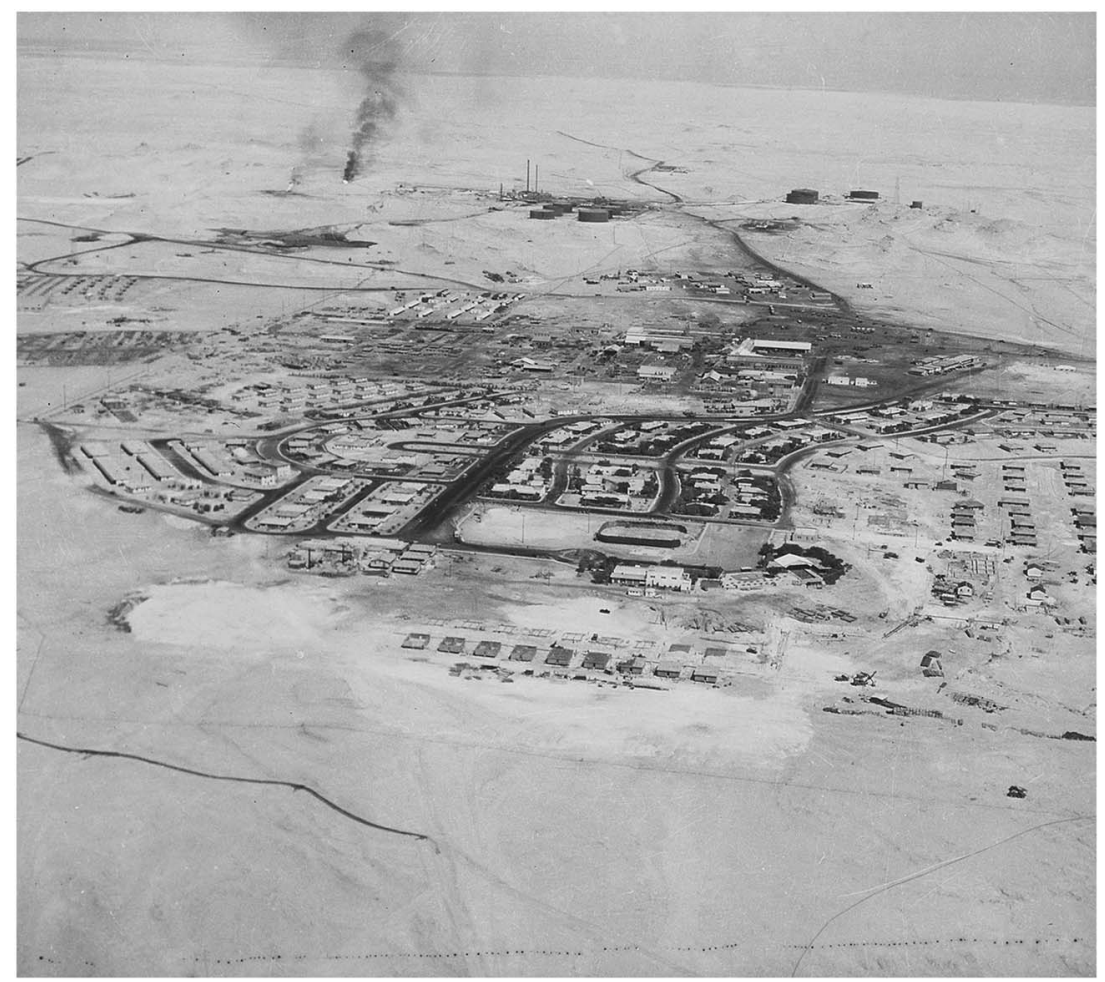

Figure 6. Aerial View of Dhahran, Saudi Arabia.

R.S. Leonard/Saudi Aramco World/SAWDIA. Used with permission.

workforce. The head of the committee, 'Abd al-'Aziz al-Sunayd, was a communist. Born in Suq al-Shuyukh in Iraq to an Iraqi mother and a Saudi father, he was educated in Iraq where he became influenced by communist ideas. He joined ARAMCO in 1949 as a teacher's assistant and later attended summer courses at the American University of Beirut, one of the main intellectual centres of the Arab left. At ARAMCO, he founded the workers' committee with a number of Palestinian communist workers. ${ }^{46}$

The government sent a commission to look into working conditions at ARAMCO and when the workers' committee demanded formal recognition as a condition for talks with the commission, its members were arrested on is October 1953, and imprisoned in Hufuf. In protest, ARAMCO workers went on strike for around two weeks. Workers gathered in the separate camp for Saudi workers to consult, and those from the Eastern 
Province then went home to their villages and towns, where they continued to hold public meetings to discuss the development of the strike. In Qatif in particular, gatherings of workers were held in Shia mourning houses, so-called bussainiyyas, such as the bussainiyya of the al-'Awwami family in the old city. These organizational resources were distinctive to the Shia areas and were key for the labour movement in the whole region. ${ }^{47}$ The Saudi government - in close cooperation with ARAMCO - deported the leaders of the strike and many foreign workers involved in the protests. But after the death of King 'Abd al-Aziz on 9 November I953, ARAMCO was forced to make some concessions to the workers.

The era of the new King Sa ud was characterized by infighting within the royal family, which manifested itself in the emergence of the dissident "Free Princes" under the leadership of Prince Talal and the rivalry with his half-brother Faysal. The internal politics and external alliances of Saudi Arabia were in flux, and were periodically drifting towards more accountable government, symbolized by country-wide municipal elections, more workers' rights, and a rapprochement with the non-alignment movement, but also back towards repression of the workers' movement, centralization of political power, and a close alliance with the United States in the Cold War. ${ }^{48}$

ARAMCO was hence not the only arena where leftist ideologies and networks had an impact. During this period, leftist and Arab Nationalist officials were powerful in the growing bureaucracy, particularly in the Oil Ministry, which provided some room to manoeuvre for the activists employed in the oil industry. ${ }^{49}$ Left-wing and nationalist activists also won seats in municipal elections that were held in Saudi Arabia in the I950s and I960s, particularly in Qatif, Dammam, Khobar, and Hufuf. ${ }^{\circ 0}$

\section{THE STRIKE OF 1956: A RENEWED LABOUR MOVEMENT, DEMONSTRATIONS, AND REPRESSION}

After the 1953 arrests, the labour movement continued to operate clandestinely, and once those that had been fired from their jobs returned to

47. Al-'Awwami, al-haraka al-wataniyya, I, pp. 77-97, on the meetings in Qatif, see p. 86. 48. Sarah Yisraeli, The Remaking of Saudi Arabia: The Struggle between King Saud and Crown Prince Faysal, 1953-1962 (Tel Aviv, 1997).

49. This is discussed in detail in Vitalis, America's Kingdom.

50. "Min qawafil al-shuhada': al-shahid Hasan Salih al-Jishi”, pp. 56-57; al-'Awwami, al-haraka al-wataniyya, I, p. I48; Phebe Ann Marr, Election in the Baladiyah of Qatif, Dhahran, 23 August 1960, Mulligan Papers; idem, Confidential Memorandum "Municipal Election Hofuf”, I9 December 1960, Dhahran, Box 3, Folder 4, Mulligan Papers. See also Toby Matthiesen, "Center-Periphery Relations and the Emergence of a Public Sphere in Saudi Arabia: The Municipal Elections in the Eastern Province, 1954-1960", British Journal of Middle Eastern Studies (forthcoming). 
ARAMCO, the activists again sought to mobilize the workers. Foreign teachers from Syria, Lebanon, and Palestine continued to spread leftist and pan-Arab ideas, and when the leaders of the 1953 strike were released in I955, they held secret weekly discussion sessions with the workers about the future of the labour movement. ${ }^{\text {II }}$ The renewed labour movement came at the height of the cooperation between Saudi Arabia and Egypt, and the refusal of Saudi Arabia to sign the Baghdad Pact that was launched in February 1955 as an alliance of conservative Middle Eastern regimes. The government sent another commission to investigate the situation of the workers in May I 956. When King Sa ud visited Dhahran in 1956, a demonstration called for the removal of the American military base there and the nationalization of ARAMCO. This was a calculated provocation, even though the demonstrators did not directly denounce the King..$^{52}$

In early June 1956 a general strike was held at ARAMCO with workers demanding better working conditions, better pay, and the right to unionize. This strike was, however, harshly suppressed and a decree forbidding any form of strike was issued thereafter. In mid-June a fight broke out in Ras Tanura when Saudi ARAMCO workers tried to storm a movie theatre from which they were barred on racial grounds. The security personnel, assisted by the personal guard of the governor, beat the protesters back, killing and injuring several. News of the incident quickly spread around the province, including to Qatif, where students from ARAMCO schools held a meeting, and tensions were running high. ${ }^{53}$

The state responded with repression and in the aftermath of the strikes, the leaders of the labour movement were imprisoned and demonstrations, labour unions, and strikes were banned. ${ }^{54}$ The three critical newspapers were closed down and their editors briefly arrested.55 Whereas the first wave of arrests targeted the activists in ARAMCO, later on also those outside the company who had been involved in the labour movement suffered repression. However, some of the leaders such as Nasir al-Sa id were able to flee. Nasir al-Sa id, who was originally from Hail in the north of the country, is widely believed to have been a leader of the strikes and a founding member of the National Reform Front (jabhat al-islah

5. Al-'Awwami, al-haraka al-wataniyya, I, pp. I8 8 f.

52. Ibid., pp. 192-194.

53. Ibid., pp. 194-198; Vitalis, America's Kingdom, pp. I 59 f.

54. For more details of the 1956 protests and strike see Vitalis, America's Kingdom, pp. I $58-193$.

55. While only four issues of al-Fajr al-Jadid were published in 1955, Akbbar al-Dhabran was closed in February 1956 and its editor 'Abd al-Karim al-Juhayman briefly arrested; 'Abdallah ibn Nasir al-Subay'i, al-haya al-ilmiyya wa-l-thaqafiyya wa-l-fikriyya fi al-mintaqa al-sharqiyya 1930-1960 [The Scholarly, Cultural and Intellectual Life in the Eastern Province 1930-1960] (Riyadh, 1987), pp. 103-107; Evans, US Records, IV, pp. 25 of., 262-265, 33 I; Jones, Dogma of Development, pp. I70-2 19; Vassiliev, History of Saudi Arabia, p. 340. 
al-watani). He escaped Saudi Arabia to Damascus after the strike in 1956 and founded the Nasserist Union of People of the Arabian Peninsula (ittihad sha'b al-jazira al-'arabiyya). ${ }^{56}$

Many others were imprisoned in Dammam and in the former Ottoman prison in the old town of Hufuf in al-Ahsa. After the first arrests a delegation of Qatifi notables under the leadership of the Shia judge of Qatif, Muhammad 'Ali al-Khunayzi, went to see governor Su'ud bin Jiluwi to try to have the prisoners released. But the latter reacted angrily and refused. ${ }^{57}$

\section{THE INFLUENCE OF EGYPTIAN PRESIDENT NASSER}

When King Sa ud visited the Eastern Province together with Egyptian President Nasser in I956 large crowds came to greet the two, but they were particularly supportive of Nasser. Nasser was very popular amongst many Saudis, especially in the Eastern Province and the Hijaz, and some Saudi political activists started to adopt Nasserism as a political ideology. His vision of economic development, anti-colonialism, and Arab nationalism appealed to many, including to some princes and some of the up-and-coming officials in the bureaucracy. ${ }^{58}$

Reflecting the position Nasser enjoyed across the Arab world, some of the political prisoners decided to separately write to Nasser and King Sa ud demanding their release. The letters reached both, but Nasser did not want to get involved in domestic Saudi affairs at this point, and refused to use diplomatic pressure to have the prisoners released. ${ }^{59}$

Soon thereafter, in the fall of 1956, another group of political activists was arrested for the distribution of subversive leaflets. Political propaganda had been found in the house of a Shia cleric from Saihat, 'Abd al-Muhsin al-Nasr, who was subsequently arrested. Ja far al-Nasr, the son

56. In 1979 he claimed to have masterminded the takeover of the Grand Mosque in Mecca and disappeared in Beirut later the same year. Opposition accounts generally state that he was killed by Saudi Intelligence with the help of an armed Palestinian group; Abir, Saudi Arabia: Government, pp. 35f.; Evans, US Records, IV, pp. 66If.; J.E. Peterson, Historical Dictionary of Saudi Arabia (Metuchen, NJ, 1993), pp. I Igf. See also Nasir al-Said, tarikh Al Su'ud [The History of Al Saud] (Beirut, I984); Nasir al-Sa'id, haqa'iq 'an... al-qabr al-su'udi [Truths about [...] Saudi Oppression] (London, I988), pp. 73-85, I 5 I-I 53.

57. The prisoners included 'Abdallah al-Jishi, Mansur 'Abdallah Ikhwan, Yusuf and Ahmad al-Shaykh Yaqub, 'Ali al-'Awwami and Hamad al-Duhami; Al-'Awwami, al-haraka al-wataniyya, I, pp. 198-203. For an account of the situation in Hufuf prison and a list of political prisoners there, see al-'Awwami, al-haraka al-wataniyya, I, pp. 216-237, 26I-263; Ya'qub, al-musa'ala, pp. 107-I 8.

58. 'Adnan, al-sajin 32; Nur al-Din bin al-Habib Hajlawi, ta'thir al-fikr al-nasiri 'ala al-khalij al-arabi 1956-197I [The Impact of Nasserist Thought on the Arabian Gulf 1956-1971), 2nd. edn (Beirut, 2010), pp. 83-148; Makki, "al-haraka al-nasiriyya”.

59. Al-'Awwami, al-haraka al-wataniyya, I, pp. 21 zf., $258 \mathrm{f}$. 
of 'Abd al-Muhsin, an activist and ARAMCO worker, had distributed the leaflets. The leader of the small group that had produced the leaflets was an Iraqi, who had been given Saudi citizenship during his work at ARAMCO. After he was released from prison he was stripped of his Saudi citizenship. ${ }^{60}$

When King Sa ud visited the Eastern Province again, the new Shia judge of Qatif, Muhammad Salih Al Mubarak, asked the King for the release of the political prisoners. Probably because of this and similar requests the political prisoners were released on 27 October 1957. One can assume that by that time the regime felt sufficiently in control of the workers' movement to take this step. ${ }^{61}$ Given its geographical proximity and historical links to Egypt, however, the influence of Nasserism was even bigger in the western Hijaz region than in the Eastern Province. ${ }^{62}$

\section{IDEOLOGICAL DIVISIONS, THE COMMUNISTS, AND THE FOUNDATION OF OPPOSITION PARTIES}

The ban on all protests and strikes, the harsh crackdown on the leaders of the workers' movement and the gradual amelioration of the situation of Saudis in ARAMCO prevented large-scale strikes after 1956. Instead, what had started as a class-based workers' movement with the limited goal of achieving a betterment of working conditions at ARAMCO turned into a political struggle, and those leftists that continued to be active after 1956 formed secret groups that sought wide-ranging social and political change across all of Saudi Arabia. ${ }^{63}$ The leaders of the 1956 strike at ARAMCO were imprisoned together in the old prison of Hufuf. While the leftist activists from different ideological strands had initially worked together, it seems that the time they spent together in prison led to a sharpening of ideological divisions. The main cleavage was between Marxists and Arab nationalists. In prison, the nucleus for the first underground political parties, which would be founded along different ideological lines, was laid. ${ }^{64}$

A number of activists had already in 1954 founded the National Reform Front, which was renamed National Liberation Front NLF (jabhat al-taharrur al-watani) around 1957/8. This group, which had its supporters mainly in the labour movement in the Eastern Province, initially combined various ideological currents, although it had a strong communist element. 
The main currents amongst the secular Saudi opposition were the orthodox communists, the Marxists that wanted to remain independent of official Soviet communism, and the nationalists (qawmiyyin), which comprised various strands of Baathists, Arab nationalists, and Nasserists. In exile, they aligned themselves to the shifting foreign policy preferences of the respective revolutionary regimes. The divisions of the Arab left thus reflected on the local scene and fragmented the Saudi leftists, whose numbers were anyway limited, even further.

The NLF used the annual hajj to Mecca in 1958 to distribute leaflets to the pilgrims, which demanded not only the liberation of ARAMCO workers but also equal treatment of Shia and Sunnis and the abolition of special levies on the Shia. ${ }^{65}$ The NLF entered into various alliances with, amongst others, the Arab National Liberation Front ANLF (jabhat al-taharrur al-watani al-'arabiyya) of the dissident Saudi prince Talal bin 'Abd al-Aziz. ${ }^{66}$ This was an eclectic group that comprised some of the "Free Princes" around Talal, as well as Shaykh Ibrahim bin Taqiqa, 'Abd al-'Aziz al-Sunayd, 'Abdallah al-Tariqi, and the Shia cleric 'Abd al-Karim al-Humud from Saihat. Although the latter was not an ARAMCO worker, he had participated in the demonstrations in 1956, was briefly imprisoned, and left for Beirut the same year. ${ }^{67}$ In Beirut he also worked together with Nasir al-Sa id and the Saudi government revoked his citizenship because of his oppositional activities. $^{68}$

After the I4 July Revolution in Iraq in 1958, which overthrew the monarchy, the Communist Party of Iraq was able to operate more openly. ${ }^{69}$ This gave a boost to the communists in the region, including in Saudi Arabia. 'Abd al-'Aziz al-Sunayd, who was half Iraqi and one of the leaders of the Saudi communists, left for Iraq. But when the communists

65. The leaflet is translated in Evans, US Records, IV, pp. 655-659.

66. I will not go into details about the Free Princes Movement here, since it has received the bulk of attention in discussions of opposition in Saudi Arabia in the I950s and I960s. Talal and his fellow royals had stopped their oppositional activities by 1963 and had returned to Saudi Arabia by 1964; Al-'Akri, al-tanzimat, pp. 39f.; Peterson, Historical Dictionary of Saudi Arabia, p. I2I.

67. Al-Humud has published his memoirs on the events in 1956 under the heading "ARAMCO and the Workers: the Revolution of the Workers", in 'Adnan al-Attar, al-harakat al-tabarruriyy fi al-Hijaz wa-Najd: 190I-I973 [The Liberation Movements in the Hijaz and Najd: 190I-I 973] (n.p., I973), pp. 56-68. He stayed there for almost two decades, continuing his oppositional activities as well as his religious studies with leading Shia scholars. He was responsible for "workers' affairs" and a representative of the Shia in the ANLF; ibid., pp. 56, I 5 I. See also Salameh and Steir, "Political Power and the Saudi State", p. 20.

68. Al-'Awwami, al-haraka al-wataniyya, I, pp. $250 f$.

69. For more on the Iraqi communists, see Johan Franzén, Red Star over Iraq: Iraqi Communism before Saddam (London, 201 I); Tareq Ismael, The Rise and Fall of the Communist Party of Iraq (Cambridge, 2007). 
became increasingly persecuted in Iraq and became one of the main internal enemies of the Iraqi Baath Party, he moved to Beirut and became the representative of the Saudi communists abroad. After his departure the local Saudi communists had to reorganize themselves. A triumvirate took over the leadership in the Eastern Province: 'Ali al-'Awwami, a Qatifi notable that had worked in Qatif municipality, became the cell leader in Qatif, while Yusuf al-Shaykh Ya'qub, the former editor of the radical paper al-Fajr al-Jadid, became the cell leader in Khobar and Dammam. ${ }^{70}$

\section{ARAB NATIONALISTS IN ARABIA BETWEEN THE SYRIAN AND THE IRAQI BAATH}

Some Saudi workers at ARAMCO also became followers of the Baath Party, partly influenced by the ideas of non-Saudi Arab teachers or workers and partly by Saudi students returning from Baghdad, Damascus, Cairo, and Beirut. They included Muhammad al-Rabi, an ARAMCO worker who was arrested in 1956 and died in prison, ${ }^{71}$ and the Shia notable Mirza al-Khunayzi. 'Ali Ghannam from Jubail, who had been working for ARAMCO since I950, was another of the early activists and later became the public face of the Saudi Baath Party abroad. They founded the Organization of Free Men of the Arabian Peninsula (munazzamat ahrar al-jazira al-arabiyya), which was the nucleus for the Saudi Baath Party, and participated in the labour mobilization at ARAMCO in $1956 .^{72}$

The Baathists only assumed the name Arab Socialist Baath Party in Saudi (hizb al-ba'th al-'arabi al-ishtiraki fi al-su'udiyya) a few years later. The Party published a secret journal - Sawt al-Jamahir (Voice of the Masses) - from I96I onwards. The Baathists in Saudi operated according to the general structure of organization that the Baath Party had developed in other countries. It was very hierarchical, made up of clandestine cells (khaliyya) of perhaps half a dozen members. Between three and seven cells formed part of a division (firqa), two to five of whom were

70. 'Abdallah Ibrahim al-Huqayl became the third leader in the Eastern Province; Al-'Awwami, al-haraka al-wataniyya, II, pp. IIf.

7I. Sawt al-Talia, 2 (1973), pp. 63-65.

72. Al-Mudayris, al-baithiyyun, p. 52f.; Evans, US Records, IV, pp. 66If. Najib al-Khunayzi claims munazzamat ahrar was founded in 1958; Najib al-Khunayzi, "al-ihtifa" bi-l-shakhsiyya al-wataniyya al-bariza Mirza al-Khunayzi" [The Celebration of the Outstanding National Personality Mirza al-Khunayzi], Rasid.com (24 December 2009). Established in 2003, Rasid became the main news portal for Saudi Shia. The editors of Rasid announced on 6 June 20I 4 that they would stop their publication and erased the archive of the website. This probably happened due to pressure by the government. Parts of the archive can still be accessed at https:// web.archive.org/web/*/rasid.com. 
subordinated to a section $\left(s h u^{i} b a\right) \cdot{ }^{73}$ In 1963 , the Baath Party in Saudi was made up of four divisions: one in Riyadh, one on the eastern coast (including Qatif, Damman, and Khobar), another in al-Ahsa, and a fourth that combined the Hijaz and the north. ${ }^{74}$

The leaders of the Saudi section would then attend the yearly congress of the region-wide Baath Party. 'Ali Ghannam became the representative of the Baath Party branches in the "Peninsula and the Arab Gulf" in the Baath Party National Command in Iraq from the early i 960 s until I 982. . $^{75}$ Another Saudi member of the Baath Party National Command in Iraq was 'Abd al-Rahman Munif, who was born in Amman to a Saudi father and an Iraqi mother. An oil expert, who had worked in the Saudi oil industry before going abroad, he then left the Baath Party and became famous as a novelist. The first part of his pentalogy Cities of Salt in particular deals with the impact of the oil industry on the Eastern Province and the labour movement at ARAMCO. ${ }^{76}$

Baathist and other left-wing students set up the Revolutionary Students Vanguard (al-talia al-tullabiyya al-thawriyya) in 1962, which spread to Dammam, Riyadh, and Qasim, but members were arrested in $1964 .{ }^{77}$ The Baathists recruited students in schools and universities; these would read socialist and Baathist literature in weekly meetings of their clandestine cells. $^{78}$ 'Abd al-Majid al-Shammasi, who had studied in Iraq in the early I950s, became a leading member of the Saudi Baath Party in 1962. More than a dozen members of the al-Shammasi, a prominent Qatifi notable family, were imprisoned in the I950s and I960s for Baathist political activism. In the I960s 'Abd al-Majid worked in a bank first in Dammam and then in Qatif and allegedly died under torture in $1969 .{ }^{79}$ Yusuf Makki, a Shia from Saihat, became a supporter of the Party in 1963 and co-organized the demonstrations in 1967 , after which he was arrested. ${ }^{80}$

73. For more on the organizational structure of the Baath Party see Joseph Sassoon, Saddam Hussein's Ba'th Party: Inside an Authoritarian Regime (Cambridge, 20I 2), pp. $36 \mathrm{f}$.

74. Makki, "hizb al-bath", p. 294.

75. Hanna Batatu, The Old Social Classes and the Revolutionary Movements of Iraq: A Study of Iraq's Old Landed and Commercial Classes and of its Communists, Baithists, and Free Officers (Princeton, NJ, I978), pp. I 224-I 229. 'Ali Ghannam remained in Iraq until 2003, when he returned to Saudi Arabia; Mufid al-Zaydi, al-tayyarat al-siyasiyya wa-l-fikriyya fi al-khalij al-arabi (197I-2003) [The Political and Intellectual Currents in the Arab Gulf (1971-2003)] (Beirut, 2012), pp. 224-226.

76. Abdelrahman Munif, Cities of Salt (London, 1994).

77. Sawt al-Talia, I (1973), p. 25 .

78. The experience of being recruited into a cell in a Dammam high school is recounted in an autobiographical literary style; Turki al-Hamad, Adama (London, 2003).

79. Anonymous, "al-Shahid 'Abd al-Majid al-Shammasi" [The Martyr 'Abd al-Majid al-Shammasi], Sawt al-Talia, 3 (July 1973), pp. 7I-74. Makki claims that 'Abd al-Majid al-Shammasi was the secretary of the shu'ba (section); Makki, "hizb al-ba'th", p. 301 .

80. Interview with a former member of the Saudi Baath Party, Beirut, 2013. 
While the Baath Party was relatively strong amongst intellectuals and in Shia areas, it also sought to infiltrate the army but without much success. ${ }^{81}$ After 1963, severe splits divided the Baath Party between radical socialists and more militarist right-wingers, and between the Syrian and Iraqi branches. These splits on the regional level had a strong impact on the Saudis and the other Gulf branches. The left wing of the Saudi Baath Party established the Popular Democratic Front in the Arabian Peninsula (al-jabha al-dimuqratiyya al-sha biyya fi al-jazira al-'arabiyya) in I965 with Anwar Thabit as one of its leaders and Mirza al-Khunayzi as its secretary. Contrary to the right-wingers it identified itself as MarxistLeninist. Although it believed in armed struggle, it failed to actually carry out any planned attacks. ${ }^{82}$ It was initially related to the Bahraini branch of the Movement of Arab Nationalists (MAN) (harakat al-qawmiyyin al-'arab), the pan-Arab organization with a strong Palestinian base founded by George Habash. ${ }^{83}$

The other Saudi Baathists who were loyal to Saddam Hussein received support after the coup in Iraq in I 968 and its leaders moved to Baghdad. There, Iraqi support gained them time on Radio Baghdad and enabled the production of a periodical, Sawt al-Tali a (Voice of the Vanguard), from I 973 onwards. The journal was edited by exiled members of the Saudi Baath Party in Cairo and Baghdad, and printed in Iraq. It contained several articles on the history of the labour movement in Saudi Arabia and is a key source for this article. After the 1975 amnesty for Saudi dissidents it ceased to publish regularly, even though occasional issues were

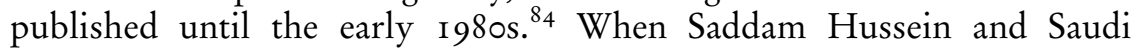
Arabia allied themselves against Iran in the Iran-Iraq war, the propaganda activities of the few remaining Saudi Baathists were curbed..$^{85}$

One of the main activities of the Saudi Baathists was their involvement in the demonstrations and riots that occurred in 1967 as a response to the

8I. See this detailed analysis of the different Army and National Guard branches and of dissident groups within the army; Sawt al-Talia, 5 (1974), pp. 8-39; 6 (1974), pp. 10-27.

82. Al-Khunayzi, "al-ihtifa"; al-Mudayris, al-ba'thiyyun, pp. $57 \mathrm{f}$.

83. Falah 'Abdallah al-Mudayris, al-harakat wa-l-jama'at al-siyasiyya fi al-Babrayn 1937-2002 [The Political Movements and Groups in Bahrain 1937-2002] (Beirut, 2004), pp. 26-32; al-'Akri, al-tanzimat, pp. Is I-I74.

84. Interview with a former member of the Saudi Baath Party, Beirut, 2013.

85. Abir, Saudi Arabia: Government, p. 36; Hamza al-Hasan, "al-mu'arada fi al-su'udiyya: al-ta'arjuh bayn al-hawa al-iqlimi wa-l-wataniyya al-jam'a" [The Opposition in Saudi: Oscillation between Regional Sentiment and Comprehensive Nationalism], al-Jazira al'Arabiyya, I 8 (July 1992), pp. 40-47; al-Mudayris, al-ba'thiyyun, pp. 56f.; David Holden and Richard Johns, The House of Saud (London, 198I), p. 532; Lackner, A House Built on Sand, p. I05; Makki, "hizb al-bath", pp. 291-301; Peterson, Historical Dictionary of Saudi Arabia, p. I20; Salameh and Steir, "Political Power and the Saudi State", p. 22; Sawt al-Talia, 2 (1973), p. 27. 
Six-Day Arab-Israeli war. The demonstrations involved several thousand people in Dhahran, Ras Tanura, Qatif, and Dammam, leading to attacks on the American Consulate in Dhahran as well as on ARAMCO infrastructure. ${ }^{86}$ The arrests of hundreds of activists in 1967 and 1969 after a foiled coup attempt dealt a blow to all the Saudi opposition organizations, including the Baathists. In I969, several cells accused of planning coups were dismantled, with some following in the Air Force and amongst Hijazis. As the plots concentrated in the army, where the Shia were only marginally represented, only few Shia were involved. Yet in I970, many Shia, some accused of membership in the Baath Party, were arrested, although this may have been related to Shia religious processions at the same time. ${ }^{87}$

\section{FROM PALESTINE TO THE GULF: THE MOVEMENT OF ARAB NATIONALISTS}

A coup plot in 1969 (one of several in the late I960s) has been attributed to the Movement of Arab Nationalists (MAN). ${ }^{88}$ Kuwaitis had traditionally led the Gulf wing of MAN but the non-Kuwaiti members from the Gulf decided during a secret conference in Dubai in 1968 to form national branches for each territory of the Gulf. The Saudis established the National Revolution Organization in Saudi NROS (munazzamat al-thawra al-wataniyya fi al-su'udiyya). ${ }^{89}$ In 1969/1970 the latter formed the Marxist-Leninist Popular Democratic Party in the Arabian Peninsula PDPAP (al-hizb al-dimuqrati al-sha'bi fi al-jazira al-'arabiyya) with the remaining cadres of the Popular Democratic Front in the Arabian Peninsula such as Anwar Thabit. ${ }^{90}$

The Party wanted to remain independent of foreign regimes and to spread across the whole of Saudi Arabia, and so a committee of four,

86. Local Government Relations, The June 1967 Riots, 26 July 1967, Box 16, Folder 8, Mulligan Papers; Al-Khunayzi, "al-ihtifa"; Anthony Cave Brown, Oil, God, and Gold: The Story of Aramco and the Saudi Kings (Boston, MA, 1999), pp. 272-280; Ibrahim, Shi is, p. I I ; Lackner, A House Built on Sand, p. Ior; Vassiliev, History of Saudi Arabia, p. 370. Abir argues that this was organized by Nasir al-Sa id's group; Abir, Saudi Arabia in the Oil Era, pp. I I If.

87. Sawt al-Talia, the periodical of the Saudi Baath Party branch sponsored by Iraq, probably exaggerates when it claims that 2,500 people were arrested after 1969, 400 of them in Qatif. Whatever the number of arrests, repression was harsh: 5 Qatifis died in custody, some of them under torture - the aforementioned Hasan al-Jishi, as well as 'Abd al-Wahid 'Abd al-Jabbar, Majid al-Shammasi, Hasan al-'Umran, and Ahmad 'Atuq; Sawt al-Talia, I (1973), p. 29. A former Baath Party member argues that when the Baathists were rounded up in 1969, there were around 300 in prison in Jeddah that were accused of being members of or associated with the Baath Party; interview with a former member of the Saudi Baath Party, Beirut, 2013.

88. Lackner, A House Built on Sand, pp. ro2f.

89. Al-'Akri, al-tanzimat, pp. 72-80, $202 \mathrm{f}$.

90. Al-Mudayris, al-batthiyyun, pp. 58f.; al-'Akri, al-tanzimat, pp. 202-2 I I; Lackner, A House Built on Sand, p. ros. 
composed of Mirza al-Khunayzi and 'Abd al-Muhsin al-Khunayzi in the Eastern Province as well as one Najdi and one Hijazi, was set up. It was common for different members of a family to become politicized and join the same movements. 'Abd al-Muhsin al-Khunayzi worked together with Mirza al-Khunayzi until the latter's arrest in 1969. Unlike other members of the al-Khunayzi family, who were based in the old city of Qatif, 'Abd al-Muhsin had grown up in the village of Awwamiyya. This was one of the reasons why he did not join the communists or the Baath Party, who had their power base in the old town of Qatif. The PDPAP, on the contrary, was popular in Shia villages such as Awwamiyya, Safwa and then in Saihat..$^{9 \mathrm{r}}$

It maintained limited links to MAN and its Palestinian branch, the Popular Front for the Liberation of Palestine (PFLP). Some Saudis fought with the PFLP against Israel but the main area of cooperation between the Gulf leftists and the MAN was Dhufar. Together with Dhufari tribal groups, MAN led a guerrilla insurgancy in the Dhufar mountains of Oman. Particularly the Kuwaiti and Bahraini MAN branches were heavily involved in Dhufar, but the Saudi branch of MAN also supported this rebellion and a couple of its members were active there. The first foreign fighter that died supporting the Dhufar rebellion was a Saudi, and Saudi leftist movements solidarized themselves with Dhufar. ${ }^{92}$

In I971, the PDPAP was weakened by the breakaway of two factions, the Popular Struggle Front (jabhat al-nidal al-sha'bi), which published the journal al-Nidal (The Struggle), and the National Liberation Front in Saudi (jabhat al-taharrur al-watani fi al-su'udiyya). By 1972 many PDPAP members were arrested in the Hijaz, Riyadh, and the Eastern Province, reflecting its cross-regional and cross-sectarian membership. It probably had several hundred members, roughly half of them Shia. ${ }^{93} \mathrm{It}$ was also the possibly first Saudi opposition group to have a female wing. Four women were arrested in 1969. Although it hoped to liberate the country by armed struggle the remaining cadres left Saudi Arabia after 1972 and used Damascus, Beirut, and south Yemen to publish the journal al-Jazira al-Jadida (The New Peninsula) from 1972 to 1974. South Yemeni support also enabled the broadcast of its radio programme

91. Interview with descendants of a former member of the PDPAP, London, 2010.

92. This was "Ali Muhammad al-Muslim, whose nom de guerre was "Comrade Nayif"; al-Jazira al-Jadida, I (March 1972); al-Akri, al-tanzimat, pp. 204f.; Abdel Razzaq Takriti, Monsoon Revolution: Republicans, Sultans, and Empires in Oman 1965-1976 (Oxford, 2013), p. I26. For declarations of solidarity with the cause of Dhufar, see, for example, the supporting statements by the Saudi Communist Party and hizb al-'amal al-ishtiraki fi al-jazira al-'arabiyya on the twentieth anniversary of the start of the Dhufar Revolution; Sawt al-Thawra, 460, July/ August 1985 , p. 20.

93. Interview with descendants of a former member of the PDPAP, London, 2010. 
Sawt al-Jazira al-'Arabiyya (Voice of the Arabian Peninsula) into the Kingdom until $1975 .{ }^{94}$ Reflecting the strong membership of Shia, PDPAP not only used class analysis in its publications but also explicitly condemned sectarian discrimination in Saudi Arabia. ${ }^{95}$

\section{CO-OPTION, THE COMMUNIST PARTY AND THE UPRISING OF 1979}

Upon King Khalid's accession to the throne in I975, a general amnesty was issued to release the remaining political prisoners from the secular opposition movements and allow those abroad to come home. The returnees became integrated into the patronage networks of the Saudi rentier state that had flourished since the oil crisis in 1973 and established themselves as "liberals" in the Saudi intellectual field. ${ }^{96}$ Some, such as 'Abd al-Karim al-Humud, became integrated into Shia notable politics. ${ }^{97}$ The former Saudi communist leader Ishaq al-Shaykh Ya'qub settled in Bahrain, where he became an apologetic defender of the Bahraini ruling family. ${ }^{98}$

The amnesty also led to the dissolving of PDPAP, which ceased its propaganda activities and whose members returned.9 ${ }^{99}$ Hizb al-'amal al-ishtiraki fi al-jazira al-'arabiyya (Socialist Action Party in the Arabian Peninsula), hereafter hizb al-'amal, became the ideological successor to PDPAP, as it was also Marxist-Leninist and aligned to MAN and PFLP. Saudi students in the United States, who had come under the influence of Arab nationalism, founded the Party in 1972. At that time there were several left-wing currents fighting for dominance in the Organization of Arab Students (munazzamat al-talaba al-'arab) in the US: Baathists

94. Al-Hasan, "al-muarada"; al-Mudayris, al-ba'thiyyun, pp. 58-60; al-'Akri, al-tanzimat, pp. 202-2 I3; Halliday, Arabia without Sultans, p. 69; Lackner, A House Built on Sand, p. ro5; Makki, "harakat al-qawmiyyin", pp. 467-486; Peterson, Historical Dictionary of Saudi Arabia, p. I 20; Yassini, Religion and State, p. I 22.

95. See, for example, al-Jazira al-Jadida, 7 (December 1974), pp. I 2-22.

96. Abir, Saudi Arabia: Government, p. 57; Steffen Hertog, Princes, Brokers, and Bureaucrats: Oil and the State in Saudi Arabia (Ithaca, NY, 2010), p. 99; Najib al-Khunayzi, "al-nishat al-siyasi li-l-shi'a fi al-su'udiyya" [The Political Discourse of the Shia in Saudi], Rasid.com (25 October 2003); Rayed Khalid Krimly, "The Political Economy of Rentier States: A Case Study of Saudi Arabia in the Oil Era 1950-1990" (Ph.D., George Washington University, 1993), p. 349; Stéphane Lacroix, Awakening Islam: The Politics of Religious Dissent in Contemporary Saudi Arabia (Cambridge, MA, 20I I), pp. I 5-20.

97. Throughout the 1980 s and I990s, al-Humud was an emissary in the negotiations between the Saudi Shia opposition and the ruling family; Ibrahim, Shii is, p. I 80.

98. He particularly denounced the widespread protest movement in Bahrain since $20 \mathrm{II}$ and defended the government crackdown in regular columns for the pro-regime al-Ayyam newspaper. See for example: Ishaq al-Shaykh Ya qub, “i4 Fibrayir [...] wa I4 Fibrayir” [I4 February [...] and I4 February], al-Ayyam, I4 February 20I3, http://www.alayam.com/writers/7018.

99. Al-'Akri, al-tanzimat, pp. 205-2I I. 
(mainly the Iraqi-wing), communists, Arab nationalists, and Libyans. The thousands of Saudi students in the US were important in this organization and the different currents tried to influence them and make them read their publications. ${ }^{100}$

Eventually, many hizb al-amal members returned to Saudi Arabia, in particular to the Eastern Province, and became bureaucrats or journalists. Hizb al-amal demanded an end to discrimination of the Shia and, like its predecessor, advocated armed struggle, even though little was heard of this until its involvement in the uprising in the Eastern Province in 1979. ${ }^{\text {IOI }}$

While a communist faction had existed within the NLF and the ANLF since I96I, the Communist Party in Saudi (al-hizb al-shuyu i fi al-su udiyya, hereafter the Communist Party), was only officially established in 1975. The Communist Party held a founding congress in which it aligned itself staunchly to official Soviet communism, and demanded a constitution, a parliament, and the nationalization of oil resources in Saudi Arabia. ${ }^{102}$ After 1975, hizb al-'amal and the communists were the only active Saudi leftist groups. The actual membership of the Communist Party, though, was limited and did not exceed $100 .{ }^{103}$

Both groups participated in the Shia uprising in the Eastern Province in $1979 .{ }^{104}$ As Shia Islamists led that uprising, the leftists joined the demonstrations independently: they carried their own banners and tried to urge the Islamists not to use sectarian slogans, reminding them that "Saudi Arabia is not Iran". They argued that protesters should focus on wider issues and that the government would use a sectarian discourse as a pretext

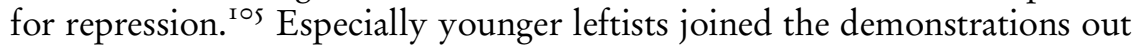

ı००. Interview with 'Abd al-Nabi al-'Akri, London, July 20 Io.

ıо I. There were other hizb al-'amal al-ishtiraki branches in Palestine, Lebanon, Iraq, and other countries, with which the Saudi hizb al-amal maintained relations. Interview with an (unnamed) representative of hizb al-'amal al-ishtiraki al-'arabi fi al-jazira al-'arabiyya in February 1984, printed in MERIP Reports, I 30 (February 1985), pp. I 5-19. See also al-Hasan, "al-mu arada"; al-Akri, al-tanzimat, pp. 214-227.

I02. Al-'Attar, al-harakat, pp. I 54, I76f.; Mark N. Katz, Russia and Arabia: Soviet Foreign Policy toward the Arabian Peninsula (Baltimore, MD, 1985), pp. I42f.; Salameh and Steir, "Political Power and the Saudi State", pp. 2of.; Aryeh Y. Yodfat, The Soviet Union and the Arabian Peninsula: Soviet Policy towards the Persian Gulf and Arabia (London, 1983), pp. I33f. I03. Interview with a former Saudi communist, Saudi Arabia, 20 I I. Some speak of only thirty members, with most living in exile; Holden and Johns, The House of Saud, p. 532; Peterson, Historical Dictionary of Saudi Arabia, p. I 2 I.

I04. Al-Akri, al-tanzimat, pp. $2 \mathrm{I} 7 \mathrm{f}$. For an account of the events in the hizb al-'amal journal see al-Masira, Io (June i980), rof. For an account in the Baath Party journal, see Sawt al-Talia, 22 (1980).

105. Ahdath november (muharram) I979 $f i$ al-suiudiyya [Events of November (Muharram) 1979 in Saudi] (n.p., n.d.), pp. 2 If.; Toby Jones, "Rebellion on the Saudi Periphery: Modernity, Marginalization, and the Shia Uprising of 1979", International Journal of Middle East Studies, 38 (2006), pp. 21 3-233, $226 \mathrm{f}$. 
of a feeling of "communal solidarity" with fellow Shia and a desire to revolt, overcoming the boundaries of political affiliation after the first waves of violence. ${ }^{\mathrm{I} 06}$ The communists even claimed that in the first days of the uprising, the protests spilled over to Khobar and Dammam. ${ }^{107} \mathrm{~A}$ few days before the start of the uprising in the Eastern Province, an armed group of rebels led by Juhayman al-'Utaybi stormed the Grand mosque in Mecca. ${ }^{108}$ Like the Shia Islamists, the leftists tried to link the takeover of the Grand mosque in Mecca with the uprising in the Eastern Province. Unlike the Islamists, however, they did not see it as an Islamic uprising cutting across sectarian and geographical divisions, describing both events instead as part of a broad-based people's revolution in Saudi Arabia. ${ }^{109}$

\section{CONCLUSION}

Organized political mobilization in the Eastern Province of Saudi Arabia can be traced back to the labour movements at ARAMCO in the I950s. At that time, the Eastern Province experienced strikes and the influence of a whole range of secular movements and ideas, from Nasserists and Baathists to communists. The oil industry profoundly changed the Eastern Province and led to rapid development, increased economic activity, and jobs for many. But it also profoundly altered the social composition of the province, led to the creation of the first labour movements and to heightened expectations about what oil income should achieve for the population. The strikes showed that at least a certain mobilization capability along class lines existed in the I950s. As such, far from just pacifying the population, the influx of oil money and migrants also fuelled the first dissident movements in the kingdom. The labour movement and the leftist activism was facilitated by a public sphere of newspapers and the dissemination of ideologies from the centres of radical politics in the Arab world through migrating teachers, students, and workers.

In the eyes of these activists, the Gulf region and the whole Arabian Peninsula was a transnational field, in which cross-border cooperation between activists was a necessity. The proximity to the British protectorate island of Bahrain was another key factor. There, the notion of labour rights and representation had been introduced earlier, and Bahrain was used

106. Louër, Transnational Shiite Politics, p. I63.

107. Ahdath november, p. 24.

I08. The rebels were largely made up of dissatisfied tribesmen and expected the return of the Mahdi [saviour].

109. Sarot al-Talia, 22 (1980). A Saudi Baathist also published a book on the Mecca events. See Thomas Hegghammer and Stéphane Lacroix, "Rejectionist Islamism in Saudi Arabia: The Story of Juhayman al-'Utaybi Revisited", International Journal of Middle East Studies, 39 (2007), pp. 103-I22, II9. 
as an organizational base by some of the Saudi labour activists. Bahraini activists also moved back and forth to the Eastern Province. Many of the connections to Bahrain were kin-based, highlighting a trend that was characteristic of the labour movement and the recruitment into the clandestine leftist and nationalist movements. Because membership of these organizations was punishable by death, recruits had to be trusted, and so militants would often recruit from within their own families and from amongst their close associates. Thus, particular families or urban quarters and villages would sometimes be affiliated with one political group.

As in other Arab countries, religious minorities such as the Shia sought refuge in non-sectarian, secular, leftist movements. Mainly members of the educated elite - the notable families - and those working for ARAMCO were drawn into these movements. The institutional resources that these Shia notables could provide for the labour movement and oppositional politics, in the form of meetings in social clubs and private houses, were of fundamental importance. They provided a link between the de-territorialized and poor workers living in the oil camps and the nationalist officials in the Oil Ministry and the labour offices of the government. Some of these officials were initially supportive of the strikers' demands, but were gradually driven out of office.

The experience of labour movements and radical politics across the Gulf states in the mid-twentieth century led regimes to look for ways to prevent such profound challenges to their rule in the future. Repression was a key tool. Widespread arrests occurred, prisoners were treated harshly, and strikes, demonstrations, and any kind of political organization were banned after 1956. But regimes also took other measures. Well aware that some of the radical ideas spread amongst the oil workers via Palestinian, Egyptian, Iraqi, Syrian, and other migrant workers and teachers, Gulf regimes would increasingly replace these highly politicized Arab migrant workers with workers from south-east Asia. The latter, who nowadays constitute the bulk of the working classes in the Gulf states, appeared to be much easier to contain. If they asked for more rights they could easily be sent back to their countries of origin. The language and cultural barriers also largely prevented cooperation with local activists.

In addition, the oil boom in the r 970 s increased the economic resources available to the regime to buy off current and potential dissidents. The economic largesse offered by the regime pacified many of the former labour activists and political dissidents. After a general amnesty in 1975 that was intended to coopt the remaining dissidents, most leftists returned to Saudi Arabia and ceased their political activities. Indeed, many former dissidents became important members of the Saudi patronage networks and the bureaucracy. The main problems of the Saudi leftist movements were their ideological differences and, apart from the strikes of the I950s, their inability to mobilize large parts of the population. As a response to 
the upsurge in leftist activism in the I950s and I960s the Saudi royal family employed Islam and a kind of tribal Arabist symbolic in order to create distinct collective identities for Saudis. ${ }^{\text {IIO }}$ Wahhabi Islam was used by the state to counter leftist and other secular ideologies. But the language of Islam therefore also became the discursive field in which the hegemonic politics of the Saudi state could be challenged. Islamist movements - both Sunni and Shia - became, from the I970s onwards, the main political forces that channelled feelings of dissent in this absolute monarchy.

\author{
TRANSLATED ABSTRACTS \\ FRENCH - GERMAN - SPANISH
}

Toby Matthiesen. Migration, minorités et réseaux radicaux. Mouvements ouvriers et groupes d'opposition en Arabie saoudite, 1950-1975.

Cet article montre comment des idées du nationalisme arabe, du socialisme et du communisme se propagèrent aux états arabes du Golfe. Il décrit comment des travailleurs migrants, des enseignants, des étudiants revenant de l'étranger, et l'émergence d'une culture d'impression remplie d'idées arabes nationalistes et gauchistes dans les années I940, créèrent la base d'une vaste mobilisation politique dans la province orientale, riche en pétrole, de l'Arabie saoudite. Après de grandes grèves en 1953 et 1956 et une dure répression, les activistes de gauche entrèrent dans la clandestinité et partirent en exil. Ils continuèrent à être actifs clandestinement et se réunirent dans de nombreuses capitales de la région. Des membres de la minorité musulmane shiite dans la province orientale jouèrent un rôle particulier dans le mouvement ouvrier et les groupes d'opposition séculaires. Ils leur promirent l'inclusion dans un projet politique élargi et semblèrent être un antidote à la discrimination confessionelle à leur encontre. L'article met en relief l'importance des réseaux transnationaux, des ressources organisationnelles telles que les bibliothèques et les clubs sociaux, et d'une sphère publique radicalisée pour la mobilisation politique.

Traduction: Christine Plard

Toby Matthiesen. Migration, Minderheiten und radikale Netzwerke. Arbeiterbewegungen und Oppositionsgruppen in Saudi Arabien, 1950-1975.

Dieser Artikel legt dar, wie sich die Ideen des arabischen Nationalismus, des Sozialismus und des Kommunismus in den arabischen Golfstaaten verbreiteten. Er skizziert, wie Arbeitsmigranten, Lehrer und aus dem Ausland zurückkehrende

I Io. See, for example: James P. Piscatori, “The Formation of the Sa udi Identity: A Case Study of the Utility of Transnationalism", in John F. Stack (ed.), Ethnic Identities in a Transnational World (Westport, CN, 1981), pp. 105-140. 
Studenten sowie die Entstehung einer mit arabisch nationalistischen und linken Ideen gesättigten Printmedienkultur die Grundlage für eine umfassende politische Mobilisierung in der erdölreichen Ostprovinz Saudi Arabiens legten. Nach den großen Streiks der Jahre I953 und I956 und der auf sie folgenden harschen Repression begaben sich die linken Aktivisten in den Untergrund oder ins Exil. Sie agierten weiterhin klandestin und sammelten sich in verschiedenen größeren Städten der Region. Angehörige der shiitischen Minderheit der Ostprovinz spielten in der Arbeiterbewegung sowie in den säkularen Oppositionsgruppen eine besondere Rolle. Solche Gruppen boten die Zugehörigkeit zu einem umfassenden politischen Projekt und stellten sich als Gegenmittel zur konfessionalistischen Diskriminierung dar, der die Schiiten ausgesetzt waren. Der Artikel betont die Bedeutung, die transnationalen Netzwerken, organisatorischen Ressourcen wie Bibliotheken und Vereinsräumen sowie einer radikalisierten Öffentlichkeit bei politischen Mobilisierungen zukommt.

Übersetzung: Max Henninger

Toby Matthiesen. Migración, minorias y redes radicales. Movimientos obreros y grupos de oposición en Arabia Saudi, 1950-1975.

En este artículo se muestra como las ideas del nacionalismo árabe, el socialismo y el comunismo se expandieron por los estados del Golfo Pérsico. En él se subraya como los trabajadores emigrantes, los maestros y los estudiantes que regresaban del extranjero, junto con la emergencia de una cultura de lo impreso marcado por el nacionalismo árabe y las ideas procedentes de la izquierda, llegaron a crear a lo largo de la década de r940 la base para una extendida movilización política en la Provincia Oriental de Arabia Saudí, una de las más ricas en la producción de petróleo. Tras las importantes huelgas de 1953 y de 1956 y las severas medidas tomadas para contenerlas, los activistas de la izquierda pasaron a la clandestinidad y al exilio. Desde allí continuaron siendo activos de forma encubierta y se reorganizaron en diferentes ciudades de la región. Miembros de la minoría musulmana chiita en la Provincia Oriental jugaron un destacado papel en el movimiento obrero y en los grupos de oposición seculares. Estos prometían su inclusión en un proyecto político mucho más amplio y se mostraban como un antídoto a la discriminación sectaria que los chiitas padecían. En el artículo se enfatiza la importancia de las redes transnacionales, los recursos organizativos tales como bibliotecas y clubs sociales, y una esfera pública radicalizada para la movilización política.

Traducción: Vicent Sanz Rozalén 